\title{
On Farm Agronomic and First Environmental Evalua- tion of Oil Crops for Sustainable Bioenergy Chains
}

\author{
Luca Lazzeri ${ }^{1 *}$, Lorenzo D'Avino ${ }^{1}$, Marco Mazzoncini² ${ }^{2}$ Daniele Antichi², \\ Giuliano Mosca ${ }^{3}$, Federica Zanetti ${ }^{3}$, Andrea Del Gatto ${ }^{4}$, Sandro Pieri ${ }^{4}$, Giuseppe De \\ Mastro $^{5}$, Nicola Grassano ${ }^{5}$, Salvatore Cosentino ${ }^{6}$, Venera Copani ${ }^{6}$, Luigi Ledda ${ }^{7}$, Roberta \\ Farci $^{7}$, Guido Bezzi ${ }^{8}$, Alessandro Lazzari ${ }^{8}$, Riccardo Dainelli ${ }^{9}$, Paolo Spugnoli ${ }^{9}$ \\ ${ }^{1}$ Research Centre for Industrial Crops, CRA-CIN Bologne, Italy \\ ${ }^{2}$ Dipartimento di Agronomia e Gestione dell'Agroecosistema, Università di Pisa \\ ${ }^{3}$ Dipartimento di Agronomia Ambientale e Produzioni Vegetali, \\ Università di Padova, Italy \\ ${ }^{4}$ Research Centre for Industrial Crops, CRA-CIN Osimo (AN), Italy \\ ${ }^{5}$ Dipartimento di Scienze delle Produzioni Vegetali, Università di Bari, Italy \\ ${ }^{6}$ Dipartimento di Scienze Agronomiche, Agrochimiche e delle Produzioni Animali, \\ Università di Catania, Italy \\ ${ }^{7}$ Dipartimento di Scienze Agronomiche e Genetica Vegetale Agraria, \\ Università di Sassari, Italy \\ ${ }^{8}$ Private consultant \\ ${ }^{9}$ Dipartimento di Ingegneria Agraria e Forestale, Università di Firenze, Italy
}

Received: 14 September 2009. Accepted: 28 October 2009.

\begin{abstract}
Energy crops, and in particular oil crops, could be an important occasion for developing new non food production rows for a new multi-functional agriculture in Italy. In this view, the use of local biomass is a fundamental starting point for the development of a virtuous energy chain that should pursue not only agricultural profitability, but also chain sustainability and that is less dependent on the global market, characterized by instability in terms of biomass availability and price. From this perspective, particular attention must be paid to crop choice on the basis of its rusticity and of its adaptability to local growing conditions and to low input cropping systems. In this context, alike woody and herbaceous biomasses, oil crops such as sunflower and rapeseed should be able to support local agricultural bioenergy chain in Italy.

In addition, in a local bioenergy chain, the role of the farmers should not be limited just to grain production; but also grain processing should be performed at farm or consortium level in oilseed extraction plants well proportioned to the cropped surface. In this way, by means of a simple power generator, farmer could thus produce its own thermal and electric energy from the oil, maximizing his profit. This objective could also be achieved through the exploitation of the total biomass, including crop residues and defatted seed meals, that may be considered as fundamental additional economic and/or environmental benefits of the chain. This paper reports some results of three-years on-farm experiments on oil crop chain carried out in the framework of "Bioenergie" project, that was focused to enhance farmers awareness of these criteria and to the feasibility at open field scale of low-input cultivation of rapeseed, sunflower and Brassica carinata in seven Italian regions. In several on-farm experiences, these crops produced more than $800 \mathrm{~kg} \mathrm{ha}^{-1}$ of oil with good energy properties. Defatted seed meals could be interesting as organic fertilizers and, in the case of B. carinata, as a biofumigant amendment that could offer a total or partial alternative to some chemicals in agriculture. Furthermore, biomass soil incorporation could contribute to $\mathrm{C}$ sequestration, catching $\mathrm{CO}_{2}$ from atmosphere and sinking a part in soil as stable humus. Finally, four different open field experiences carried out again in the second year of the project, have been analysed in order to evaluate their energy and greenhouse gasses balance after cultivation phase.
\end{abstract}

Key-words: Brassica carinata, carbon dioxide sequestration, defatted seed meals, greenhouse gasses, inputs.

* Corresponding Author: Fax: +39 051 374857. E-mail address: 1.lazzeri@isci.it 


\section{Introduction}

The decision of the European Community (Directive 2009/28/EC published in OJ 5.6.2009 and the Commission Decision of 30.6.2009 on National Renewable Energy Action Plans) on renewable energy sources has opened important development perspectives in relation to the ambitious objectives on biofuel production within the EU by 2020 . Nevertheless, clear sustainable criteria are fundamental to define new development models specific for the EU countries agricultural systems including Italian one that is characterised by both limited land availability for bioenergy crop production and higher grain production costs than those of other EC or nonEC countries. In the first two years of on-farm experiments, the "Bioenergie" project proposed a development model for the oil crop supply chain, as an alternative to the conventional industrial model currently applied in Italy.

The proposal essentially consists in the development of a local supply chain, where oil crops should be grown as break crops in cereal cropping systems in different agricultural districts at various scales (farmers' associations, cooperatives, consortia, etc.). In this context, farmers, as well as grain producers, should perform also oil extraction process by means of an onfarm mechanical plant designed according to the cropped area. Farmers thus may become producers and end-users of the energy obtained from crude vegetable oil, maximising their profit and reducing energy chain environment impact. To balance the lower potential production of oil crops in Italy if compared to other countries, a basic point could be to gamble on a "whole-use" of plant biomass, as a tool to achieve improved economic and environmental sustainability (Bezzi et al., 2007). According to the concept of "biorefinery" approach (Kamm et al., 2006; Lazzeri and D'Avino, 2008), the chemical industry should set up new cost-effective technologies to produce not only energy, but also safer chemical compounds to develop sustainable innovative strategies aimed at creating an environmentally friendly alternative to chemicals. The economic exploitation of co-product potential can improve the chances for bioenergy crop systems (Venturi and Venturi, 2003).

Food crops must obviously remain the first source of income for the national agricultural sector, but energy crops, cultivated in rotation with food crops, can contribute to increase biodiversity at farm scale and consequently to improve the qualitative and quantitative yields of the food crops in rotation. Starting from this approach, it is fundamental to increase the use of virtuous cultivation techniques in crop management (e.g. low inputs, crop rotations etc.) as much as possible in order to reduce Greenhouse gasses (GHG) emissions (Janssen et al., 2003) during cultivation phase and/or to increase the carbon sequestration potential after the incorporation of part of the biomass (crop residues, defatted seed meals). This proposal could provide a possible answer to the 2009/28/EC Directive which, for the first time, defines sustainability criteria specific for energy crops, and defines the rules for calculating the GHG impact of biofuels starting from emission during the cultivation phase.

Considering that on-farm, participatory researches can promote rapid adoption of agricultural innovations (Wuest et al., 1999; Andrews et al., 2002), allow a multidirectional flow of information among farmers and researchers (Tanaka et al., 2002).

The aim of on-farm work is to report some preliminary results achieved in 7 representative localities out of a total of 15 open field cultivation trials carried out during 2007-2008 in eight Italian Region (Fig. 1). In each experimental site, Brassica carinata (Mazzoncini et al., 1993), a model of "whole-use" energy crop (Lazzeri et al., 2007a), was compared to the most suitable oil crop for each specific agro-climatic condition: high oleic sunflower (Helianthus annuus var. High oleic (HOSO) and/or rapeseed (Brassica napus var. oleifera). A second aim of this work was to report some chemical-physical properties and the potential of defatted seed meals (DSM) in the non-food market on the basis of their chemical composition.

Finally, some results of energy and environmental balances related to four specific sites located in Veneto, Emilia Romagna, Tuscany and Apulia will be reported and discussed.

\section{Materials and methods}

\subsection{Experimental sites}

The on-farm trials of the project were carried out for three years at open field scale in private 


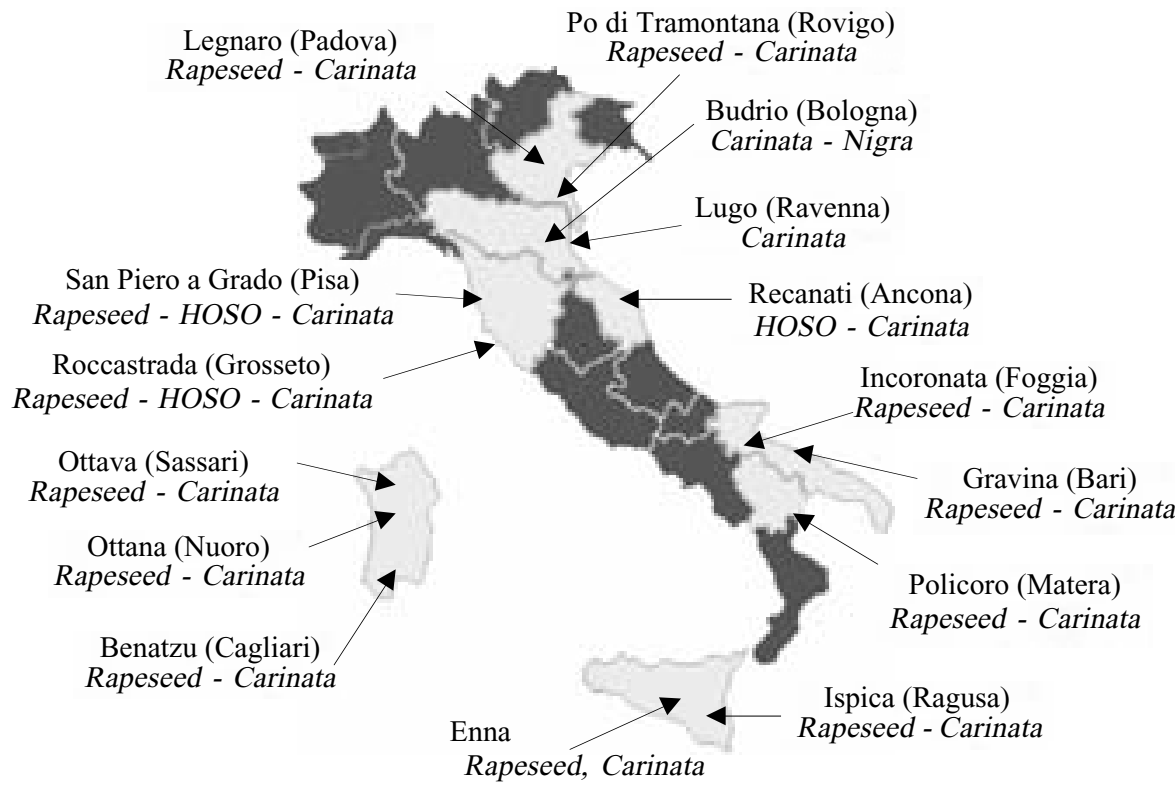

Figure 1. On farm trial locations of the "Bioenergie" project in the year 2007-2008. farms, on a surface of at least 1 ha for each crop, applying common farm mechanisation methods, even if the trials and the results were evaluated also by a three-replicate randomised samplings. The trials were located in seven Italian regions: Veneto - Po di Tramontana (Rovigo); Emilia Romagna - Lugo (Ravenna); Marches Recanati (Ancona); Tuscany - Roccastrada (Grosseto); Apulia - Gravina in Puglia (Bari); Sicily - Ispica (Ragusa) and Sardinia - Ottana (Nuoro).

The on-farm trials for the evaluation of sustainability balance were located: in Veneto - Po di Tramontana (Rovigo), Emilia Romagna - Budrio (Bologna), Tuscany - San Piero a Grado (Pisa) and Apulia - Gravina in Puglia (Bari).

\subsection{Experimental design}

The cropping techniques were defined in relation to the specific characteristics of each area, according to a common low input prescription model characterized by different energy inputs (e.g. a different expenditure of technical means, soil tillage, fertilizers and chemical treatments) as described in Table 1. In each site, Brassica carinata (carinata) and B. napus were sown between end September-beginning of October (in the north) and second half of November (in the south). Sunflower was sown in spring, between March and April.

In three localities (Tuscany, the Marches and
Apulia) low input techniques were compared to high input techniques. The differences between high and low input techniques are described in Table 2.

The cultivation techniques of the on-farm trials for sustainability balances are reported at 2.4 paragraph.

The on-farm design was long strips side-byside in the field. Typically, strips are field length and one or two tractors passes wide (Sooby, 2001).

The results of this study are referred to the data of the second year of the project (20072008) and evaluated on the basis of data collected by the whole fields and by three replications for each field strips. Replicated observations were statistically analysed using completely randomized design ANOVA performed with SigmaStat 3.11 (Systat software Inc.). LSD Fisher's protected test $(\mathrm{P} \leq 0.05)$ was applied for mean separation. The yield recorded by the harvesting of the whole fields were compared using standard errors.

\subsection{Measurements}

At ripening, (seed moisture lower than $90 \mathrm{~g} \mathrm{~kg}^{-1}$ ) three randomized sample areas of $2 \mathrm{~m}^{2}$ were collected within each experimental field to assess harvestable crop yield. The plants were manually cut and gathered and then threshed 
Table 1. Low-input cropping techniques applied at each experimental site.

\begin{tabular}{|c|c|c|c|c|c|c|c|c|c|c|}
\hline \multirow[b]{2}{*}{ Region } & \multirow[b]{2}{*}{ Sites } & \multirow[b]{2}{*}{ Crop* } & \multirow[b]{2}{*}{ Cultivar } & \multirow[b]{2}{*}{ Tillage } & \multicolumn{2}{|c|}{ Sowing technique } & \multicolumn{3}{|c|}{$\begin{array}{l}\text { Fertilization } \\
\quad\left(\mathrm{kg} \mathrm{ha}^{-1}\right)\end{array}$} & \multirow[t]{2}{*}{$\begin{array}{c}\text { Weed } \\
\text { management }\end{array}$} \\
\hline & & & & & $\begin{array}{l}\text { Inter- } \\
\text { row } \\
(m)\end{array}$ & $\begin{array}{c}\text { Seed } \\
\text { Density } \\
\left(k_{g} h a^{-1}\right)\end{array}$ & $\mathrm{N}$ & $\mathrm{P}_{2} \mathrm{O}_{5}$ & $\mathrm{~K}_{2} \mathrm{O}$ & \\
\hline \multirow[t]{2}{*}{ Veneto } & \multirow{2}{*}{$\begin{array}{l}\text { Po di } \\
\text { Tramontana } \\
(\mathrm{RO})\end{array}$} & $\mathrm{C}$ & ISCI7 & \multirow{2}{*}{$\begin{array}{c}\text { Subsoiling + } \\
\text { Disk harrowing } \\
+ \text { Rotary tillage }\end{array}$} & 0.45 & 4.5 & 130 & 90 & 90 & \multirow{2}{*}{$\begin{array}{c}\text { Chemical } \\
\text { pre-emergence }\end{array}$} \\
\hline & & $\mathrm{R}$ & Excalibur & & 0.45 & 4.5 & 130 & 90 & 90 & \\
\hline $\begin{array}{l}\text { Emilia } \\
\text { Romagna }\end{array}$ & $\begin{array}{l}\text { Lugo } \\
\text { (RA) }\end{array}$ & $\mathrm{C}$ & $\begin{array}{l}\text { CT } 207 \\
\text { ISCI7 }\end{array}$ & $\begin{array}{l}\text { Ploughing + } \\
\text { Rotary tillage }\end{array}$ & 0.15 & 8 & $0 * * *$ & 0 & 0 & \\
\hline \multirow[t]{3}{*}{ Tuscany } & \multirow{3}{*}{$\begin{array}{l}\text { Roccastrada } \\
\text { (GR) }\end{array}$} & $\mathrm{C}$ & CT207 & \multirow{2}{*}{$\begin{array}{l}\text { Disk harrowing }+ \\
\text { shallow chiselling }\end{array}$} & 0.15 & 11 & $0 * * *$ & 0 & 0 & \\
\hline & & $\mathrm{R}$ & PR46W10 & & 0.15 & 10 & $0 * * *$ & 0 & 0 & \\
\hline & & $\mathrm{H}$ & PR64H41 & $\begin{array}{l}\text { Chiselling }+ \text { disk } \\
\text { and rotary harrowing }\end{array}$ & 0.75 & $6.5 * *$ & 60 & 30 & 30 & $\begin{array}{c}\text { Chemical post } \\
\text { emergence }\end{array}$ \\
\hline \multirow[t]{2}{*}{ Marches } & \multirow[t]{2}{*}{$\begin{array}{l}\text { Recanati } \\
(\mathrm{AN})\end{array}$} & $\mathrm{C}$ & ISCI7 & $\begin{array}{c}\text { Disk harrowing }+ \\
\text { Rotary hoeing }\end{array}$ & 0.15 & 8 & 92 & 70 & 0 & \\
\hline & & $\mathrm{H}$ & PR64H41 & $\begin{aligned} & \text { Disk harrowing } \\
+ & \text { Zig zag harrowing }\end{aligned}$ & 0.50 & $6 * *$ & 119 & 70 & 0 & $\begin{array}{c}\text { Chemical } \\
\text { Pre-emergence }\end{array}$ \\
\hline \multirow[t]{2}{*}{ Apulia } & \multirow{2}{*}{$\begin{array}{l}\text { Gravina di } \\
\text { Puglia(BA) }\end{array}$} & $\mathrm{C}$ & ISCI7 & \multirow{2}{*}{$\begin{array}{l}\text { Ripper }+ \\
2 \text { Harrowing }\end{array}$} & 0.15 & 8 & 49 & 20 & 0 & \\
\hline & & $\mathrm{R}$ & PR46W10 & & 0.15 & 5 & 49 & 20 & 0 & \\
\hline Sicily & $\begin{array}{l}\text { Ispica } \\
(\mathrm{RG})\end{array}$ & $\mathrm{C}$ & $\begin{array}{l}\text { CT } 207 \\
\text { ISCI7 }\end{array}$ & Ripper + Hoeing & 0.18 & 10 & 48 & 65 & 0 & $\begin{array}{c}\text { Chemical } \\
\text { pre-emergence }\end{array}$ \\
\hline \multirow[t]{2}{*}{ Sardinia } & \multirow[t]{2}{*}{$\begin{array}{l}\text { Ottana } \\
(\mathrm{NU})\end{array}$} & $\mathrm{C}$ & BRK147 & $\begin{array}{l}\text { Ploughing + } \\
\text { Rotary tillage }\end{array}$ & 0.18 & 8 & 50 & 60 & 0 & Mechanical \\
\hline & & $\mathrm{R}$ & Kabel & & 0.18 & 8 & 128 & 92 & 0 & $\begin{array}{c}\text { Chemical } \\
\text { pre-emergence }\end{array}$ \\
\hline
\end{tabular}

* C stands for Brassica carinata; $\mathrm{R}$ for rapeseed; $\mathrm{H}$ for high oleic sunflower.

** For sunflower, sowing density is reported as plant $\mathrm{m}^{-2}$ and not as $\mathrm{kg}$ of seeds ha ${ }^{-1}$.

*** Fertilization test carried out to quantify nutrient supply from the environment.

Table 2. Differences between high and low input cultivation techniques described in Table 1.

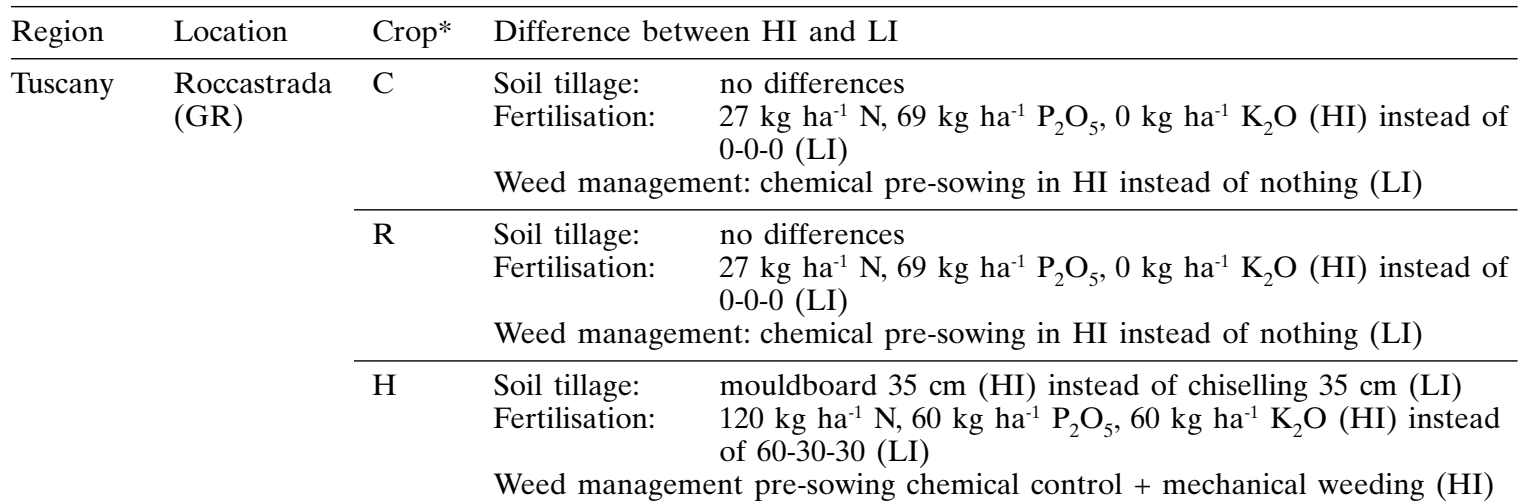
instead of post-emergence chemical weed control

\begin{tabular}{|c|c|c|c|}
\hline Marches & $\begin{array}{l}\text { Recanati } \\
(\mathrm{AN})\end{array}$ & $\begin{array}{l}\mathrm{C} \\
\mathrm{H}\end{array}$ & Soil preparation: chiseling (HI) instead of disk arrowing (LI) \\
\hline Apulia & $\begin{array}{l}\text { Gravina di } \\
\text { Puglia (BA) }\end{array}$ & $\begin{array}{l}\mathrm{C} \\
\mathrm{R}\end{array}$ & $\begin{array}{l}\text { Soil tillage: } \quad \text { no differences } \\
\text { Fertilisation: double in } \mathrm{HI}\left(97 \mathrm{~kg} \mathrm{ha}^{-1} \mathrm{~N}, 40 \mathrm{~kg} \mathrm{ha}^{-1} \mathrm{P}_{2} \mathrm{O}_{5}\right) \\
\text { Weed management: chemical pre-sowing in HI }\end{array}$ \\
\hline
\end{tabular}

* C stands for Brassica carinata; $\mathrm{R}$ for rapeseed; $\mathrm{H}$ for high oleic sunflower. HI high input cultivation techniques LI low input cultivation techniques. 
by a fixed machine, using sieves suitable for small seeds, and evaluated for their moisture, seed and crop residue yields. The moisture was measured by oven-drying the seeds at $105{ }^{\circ} \mathrm{C}$ for 24 hours. After harvesting, impurities were removed from a sample of the seed and oil, protein and glucosinolates were determined. Crop residues were evaluated for their $\mathrm{N}$ amount. After sampling, the entire field was harvested by a combine equipped with a straight cut header.

The seed oil concentration was determined by the NMR (Nuclear Magnetic Resonance) technique, using a specific calibration for each species on an Oxford Newport 4000 instrument. $\mathrm{N}$ content was determined by the Kjeldahl method assessed using an automatic titre distiller Vapodest 6 Gerhard (Germany).

A part of the seed yield was defatted by a mechanical plant of Mailca (Modena, Italy) and the residual defatted meals were assessed for Kjeldahl N, P (Cottenie et al., 1982) and C contents. Carbon content was assessed as the difference from dry matter biomass and ashes and multiplied by 0.4 , the coefficient for vegetable materials.

\subsection{Sustainability balances}

Sustainability balances was carried out merely in carinata cultivated in four localities among those reported in Figure 1. The cultivation techniques adopted was slightly different by those reported in Table 1 and 2, and characterised by high inputs in Veneto and by low inputs in Emilia Romagna, Tuscany and Apulia. In particular soil preparation was performed by mouldboards in Budrio, spading machine in Po di Tramontana, ripper in Gravina and no-tillage in San Piero a Grado. In these trials, $\mathrm{N}$ fertilization ranged between 54 in Gravina and $170 \mathrm{~kg} \mathrm{ha}^{-1}$ in Po di Tramontana, where also an emergency irrigation was needed. In Gravina no chemical weed management was applied, while in San Piero a Grado only one treatment by glyphosate was done before sowing.

The approach was essentially that of LCA (Consoli et al., 1993) but, following the indications of the recent Directive for energy crops (Dir 2009/28/EC), the analysis has been focused on assessing the Global Warming Potential (GWP), which is a measure of the global rise in temperature due to the increase of GHG in the atmosphere. The considered GHG were $\mathrm{CO}_{2}$,
$\mathrm{N}_{2} \mathrm{O}, \mathrm{CH}_{4}$. As suggested by IPCC (2001), their effects were converted into a final GWP measured in mass quantity of $\mathrm{CO}_{2}$ eq. considered over a 100-year timescale, assuming the following equivalences: $\mathrm{CO}_{2}=1, \mathrm{CH}_{4}=23$ and $\mathrm{N}_{2} \mathrm{O}=$ 296. Following the rules for calculating the GHG impact described in Dir 2009/28 EC, emissions from the manufacture of machinery and equipment has not been taken into account. Furthermore, the impact on Energy Resources Depletion (ERD) expressed in MJ of primary energy required by the production process was also evaluated.

The hectare, the mass unit of product $(\mathrm{kg})$, and one MJ of biodiesel were considered as the functional units to which impacts were referred, following the EU Directive references. Field yield expressed as mass $(\mathrm{kg})$ of biodiesel was evaluated considering the oil extracted from the grain produced in the different localities and the percentage of biodiesel obtained from carinataoil of $97.6 \%$ (Cordovani, personal communication). The extracted oil was evaluated considering the specific oil content measured as described in the previous paragraph and assuming an oil content in residual oilcake of $11 \%$ (as reported in Table 6).

To calculate the obtained Energy (Eo) value, the Net Calorific Value (NCV) of biodiesel was assumed equal to $37 \mathrm{MJ} / \mathrm{kg}$ as indicated in the Directive 2009/28/EC. Grain NCV was calculated considering B. carinata oil (ASTM D 240-07) and DSM NCV (CEN/TS, 2005).

Coefficients for primary energy consumption and GHG emissions for every unit of input applied in the cultivation process were taken from Audsley (1997), as reported in Table 3. The required energy and $\mathrm{CO}_{2}$ eq emissions coefficients for N-P-K fertilizers were calculated multiplying the percentages of $\mathrm{N}, \mathrm{P}_{2} \mathrm{O}_{5}$ and $\mathrm{K}_{2} \mathrm{O}$ by the coefficients of each macronutrient and then adding the results. The GHG emissions of use of fertilizers were not taken into account in the evaluation of $\mathrm{CO}_{2}$ eq.

\section{Results and discussion}

The conventional oil crops confirmed their feasibility as energy sources. In some locations, even under open field conditions, more than 800 $\mathrm{kg} \mathrm{ha}^{-1}$ of oil were produced (Veneto for rape- 
Table 3. Required energy (MJ) and GHG emissions $\left(\mathrm{CO}_{2} \mathrm{eq}\right)$ per unit of input following Audsley (1997).

\begin{tabular}{|c|c|c|c|c|}
\hline \multirow[t]{2}{*}{ Category } & \multirow[t]{2}{*}{ Inputs } & \multirow[t]{2}{*}{ Unit } & \multicolumn{2}{|c|}{ Coefficients } \\
\hline & & & Energy (MJ/unit) & $\mathrm{CO}_{2}$ eq. (kg/unit) \\
\hline Energy sources & Diesel & lt & 38.46 & 2.96 \\
\hline \multirow[t]{7}{*}{ Fertlizers } & Ammonium nitrate & $\mathrm{kg}$ & 12.75 & 0.38 \\
\hline & Ammonium sulphate & $\mathrm{kg}$ & 10.30 & 0.31 \\
\hline & Urea & $\mathrm{kg}$ & 31.62 & 1.33 \\
\hline & Organic NP (8-15-0) & $\mathrm{kg}$ & 8.72 & 0.58 \\
\hline & NPK $(8-24-24)$ & $\mathrm{kg}$ & 12.92 & 0.99 \\
\hline & NPK $(11-22-16)+2 \mathrm{MgO}$ & $\mathrm{kg}$ & 14.37 & 1.03 \\
\hline & Bioactyl (8-10-22) & $\mathrm{kg}$ & 8.34 & 0.55 \\
\hline \multirow[t]{3}{*}{ Pesticides } & Glyphosate & $\mathrm{kg}$ & 454.00 & 14.47 \\
\hline & Metazachlor & $\mathrm{kg}$ & 275.80 & 17.20 \\
\hline & Trifluralin & $\mathrm{kg}$ & 344.17 & 17.61 \\
\hline Seeds & B. carinata seeds & $\mathrm{kg}$ & 5.36 & 0.65 \\
\hline Labour & Farm worker & $\mathrm{h}$ & 7.30 & - \\
\hline
\end{tabular}

seed, Emilia Romagna, Tuscany, Sicily for carinata and Tuscany and the Marches for sunflower), which could be profitable in Italy (Fig. 2).

Brassica carinata confirmed its well-known rusticity and adaptability to the environmental conditions of many of the tested areas giving good grain yield and good amount of crop residues. These characteristics, linked to the relatively poor input requirements, the good resistance to water stress and to pod shattering, open good application perspectives (Zanetti et al., 2009) for this new non-food oil crop, especially for autumnal sowing in southern European areas. All the crops showed a high seed yield variability within years (data not shown) and among experimental sites (Tab. 4). The statistical analy-

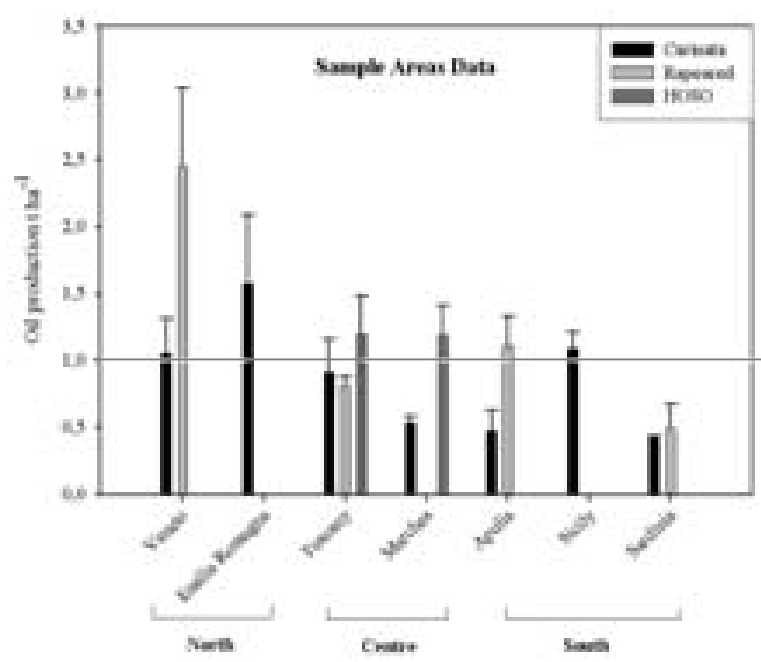

Figure 2. Oil yield of on farm trial of the tested crops. Error bars indicate standard deviation among sample areas. sis due to the high variability of on-farm cultivations of the three randomised sampling highlighted some significant yield differences among oil crops only in the Marches, even if the results obtained in Veneto and Tuscany showed large (but not significant) differences. In Veneto, Emilia Romagna, Tuscany and Sicily, carinata provided grain yields higher than $2.3 \mathrm{t} \mathrm{DM} \mathrm{ha}^{-1}$ in open fields. From these results, and considering the NCV value of B.Carinata oil, this new crop can be considered a potential additional option for bioenergy production. Further studies are needed to improve the knowledge of the agronomic and genetic aspects of this crop.

The differences in seed oil content among species were significant in many of the experimental sites except for the Marches and Sardinia trials, with sunflower and rapeseed characterised by a higher seed oil concentration if compared to carinata (Tab. 4). On the contrary, seed nitrogen content was generally higher in carinata than rapeseed (Tab. 4).

To define sustainable bioenergy chain as well as to reduce the use of energy during the plant cultivation phase is fundamental the application of low external input cultivation systems. The results of the "Bioenergie" project indicate the possibility of cultivating both conventional (rapeseed and sunflower) and new (carinata) oil crops using low input systems without a significant seed and oil yield reduction in Central and Southern Italy (Tab. 5), confirming the possibility of reducing production costs and environmental impacts.

Unlike 00 rapeseed and sunflower, carinata 
Table 4. Effect of on-farm trial location on yield components of rapeseed, carinata and sunflower.

\begin{tabular}{|c|c|c|c|c|c|c|c|c|c|}
\hline \multirow[b]{2}{*}{ Region } & \multirow[b]{2}{*}{ Location } & \multirow[b]{2}{*}{$\begin{array}{c}\text { Crop } \\
+\end{array}$} & \multirow[b]{2}{*}{$\begin{array}{c}\text { Open field } \\
\text { yield } \\
\left(\mathrm{t} \mathrm{ha}{ }^{-1} \mathrm{DM}\right)\end{array}$} & \multicolumn{3}{|c|}{ Seeds } & \multicolumn{3}{|c|}{ Crop residues } \\
\hline & & & & $\begin{array}{c}\text { Sample } \\
\text { area yield } \\
\left(\mathrm{t} \mathrm{ha} \mathrm{h}^{-1} \mathrm{DM}\right)\end{array}$ & $\begin{array}{l}\text { Oil content } \\
\text { (\% DM) }\end{array}$ & $\begin{array}{l}\text { N content } \\
(\% \mathrm{DM})\end{array}$ & $\begin{array}{c}\text { GLS } \\
(\mathrm{mmoles} \\
\left.\mathrm{kg}^{-1} \mathrm{DM}\right)\end{array}$ & $\begin{array}{c}\text { Yield } \\
\left(\mathrm{t} \mathrm{ha}^{-1} \mathrm{DM}\right)\end{array}$ & $\begin{array}{l}\text { N content } \\
(\% \text { DM })\end{array}$ \\
\hline \multirow[t]{3}{*}{ Veneto } & Po di & $\mathrm{R}$ & 4.08 & 5.38 & 45.7 & 3.5 & 18.6 & 12.8 & nd \\
\hline & Tramontana & $\mathrm{C}$ & 1.75 & 3.29 & 31.8 & 5.0 & 130.6 & 20.5 & nd \\
\hline & $(\mathrm{RO})$ & & & $\mathrm{ns}$ & $* *$ & $* *$ & $* *$ & ns & - \\
\hline Emilia & Lugo & $\mathrm{C}$ & 2.87 & 5.53 & 32.5 & 5.1 & 100.1 & 17.7 & 0.7 \\
\hline \multirow{2}{*}{ Romagna } & (RA) & $\mathrm{C}$ & 3.10 & 4.04 & 33.3 & 4.8 & 80.2 & 10.3 & 0.5 \\
\hline & & & & $\mathrm{ns}$ & ns & $*$ & $*$ & $\mathrm{~ns}$ & $*$ \\
\hline \multirow[t]{4}{*}{ Tuscany } & Roccastrada & $\mathrm{H}$ & nd & 2.61 & 46.1 & 3.0 & - & 4.5 & 0.8 \\
\hline & $(\mathrm{GR})$ & $\mathrm{C}$ & nd & 2.30 & 39.3 & 3.8 & 86.6 & 8.5 & 0.4 \\
\hline & & $\mathrm{R}$ & nd & 1.64 & 49.5 & 2.5 & 17.3 & 6.8 & 0.5 \\
\hline & & & & $\mathrm{ns}$ & $* *$ & $* *$ & $* *$ & $*$ & $\mathrm{~ns}$ \\
\hline \multirow[t]{3}{*}{ Marches } & Recanati & $\mathrm{H}$ & 1.86 & 2.63 & 45.1 & 3.8 & - & 4.8 & 1.0 \\
\hline & $(\mathrm{AN})$ & $\mathrm{C}$ & 1.12 & 1.00 & 41.7 & 3.9 & 92.4 & 0.8 & 0.3 \\
\hline & & & & $* *$ & ns & $* *$ & - & $* *$ & $* *$ \\
\hline \multirow[t]{3}{*}{ Apulia } & Gravina & $\mathrm{R}$ & 1.57 & 2.32 & 48.0 & 3.1 & 13.5 & 4.3 & 0.5 \\
\hline & di Puglia & $\mathrm{C}$ & 1.43 & 1.36 & 35.0 & 4.8 & 108.8 & 4.3 & 0.6 \\
\hline & $(\mathrm{BA})$ & & & $\mathrm{ns}$ & $* *$ & $* *$ & $* *$ & ns & ns \\
\hline \multirow[t]{3}{*}{ Sicily } & Ispica & C & & 0 & & & 624 & 56 & \\
\hline & & $\mathrm{C}$ & 2.59 & 2.64 & 40.1 & $\begin{array}{l}4.1 \\
3.6\end{array}$ & 97.4 & 3.6 & 0.4 \\
\hline & & & & ns & ns & ns & $* *$ & $*$ & - \\
\hline \multirow[t]{3}{*}{ Sardinia } & Ottana (NU) & $\mathrm{R}$ & nd & 1.10 & 45.4 & 3.1 & 13.7 & 6.3 & 0.3 \\
\hline & & $\mathrm{C}$ & nd & 1.07 & 39.5 & 4.1 & 62.3 & 10.3 & 0.4 \\
\hline & & & & $\mathrm{ns}$ & ns & $*$ & $* *$ & $* *$ & ns \\
\hline
\end{tabular}

+ C stands for Brassica carinata; R for rapeseed; H for high oleic sunflower; DM Dry Matter; N Nitrogen; GLs Glucosinolates; nd not determined. $* \mathrm{P} \leq 0.05 ; * * \mathrm{P} \leq 0.01$ ns not significant.

defatted seed meals (DSM) can not be used as a feed due to the high level of glucosinolates that causes the well known goitrogen effect (Tab. 4 and 6). All DSMs chemical composition (Tab. 6) makes their application as organic fertilizers interesting, due to the nitrogen level higher than $5 \%$ and total phosphorous amount of around $1 \%$ (Tab. 6). In addition, the high glucosinolate content makes carinata DSM a base material for the production by a patented procedure (Lazzeri et al., 2007b) of a 100\% vegetable amendment able to release in soil biologically active compounds. This technique is called Biofumigation and begins to be applied for natural control of some soil-borne pests and pathogens (Lazzeri et al., 2009; Furlan et al., 2004) and soil fertility management in horticulture production.

DSM incorporation in soil, in addition to fertilising and/or biofumigant properties, can be considered as a non-food utilisation that permits a significant $\mathrm{CO}_{2}$ sequestration from the atmosphere as stable humus in soil (Freibauer et al., 2004). This means that, year after year, a local energy chain could activate a virtuous agronomic technique aimed at improving organic matter content in soil, an aspect that, especially in some southern areas, is fundamental for maintaining sufficient soil fertility. A raw balance of the $\mathrm{CO}_{2}$ sink effect, carried out using the common isohumic coefficient of $30 \%$ (Costantini, 2004), shows that the incorporation of $1 \mathrm{t}$ of DSM could potentially sequester in soil around $160 \mathrm{~kg}$ ha year ${ }^{-1}$ of $\mathrm{C}$ that means around $0.6 \mathrm{t} /$ ha year ${ }^{-1}$ of $\mathrm{CO}_{2}$.

The soil incorporation of crop residues must also be carefully evaluated due to the relevant biomass production from 1 to $20 \mathrm{tha}^{-1} \mathrm{DM}$ with a $\mathrm{N}$ amount ranging from 0.5 to $0.7 \%$ (Tab. 4) and considering that straw biomass contains the 
Table 5. Effect of on-farm trial location on yield of rapeseed, carinata and sunflower grown under high and low input cultivation techniques.

\begin{tabular}{|c|c|c|c|c|c|c|c|c|c|c|}
\hline \multirow[t]{2}{*}{ Region } & \multirow[t]{2}{*}{ Crop* } & \multicolumn{3}{|c|}{$\begin{array}{l}\text { Grain Yield } \\
\left(\mathrm{t} \mathrm{ha} \mathrm{h}^{-1} \mathrm{DM}\right)\end{array}$} & \multicolumn{3}{|c|}{$\begin{array}{l}\text { Oil content } \\
(\% \mathrm{DM})\end{array}$} & \multicolumn{3}{|c|}{$\begin{array}{c}\text { Oil yield } \\
\left(\mathrm{t} \mathrm{ha}^{-1} \mathrm{DM}\right)\end{array}$} \\
\hline & & $\mathrm{HI}$ & LI & Mean & $\mathrm{HI}$ & LI & Mean & $\mathrm{HI}$ & $\mathrm{LI}$ & Mean \\
\hline \multirow[t]{6}{*}{ Tuscany } & $\mathrm{C}$ & 2.25 & 2.30 & $2.27 \mathrm{~b}$ & 34.5 & 39.3 & $36.9 \mathrm{~b}$ & 0.80 & 0.94 & $0.87 \mathrm{~b}$ \\
\hline & $\mathrm{R}$ & 1.78 & 1.64 & $1.71 \mathrm{~b}$ & 50.3 & 49.5 & $49.9 \mathrm{a}$ & 0.92 & 0.83 & $0.87 \mathrm{~b}$ \\
\hline & $\mathrm{H}$ & 3.17 & 2.61 & $2.89 \mathrm{a}$ & 50.6 & 45.8 & $48.2 \mathrm{a}$ & 1.72 & 1.26 & $1.49 \mathrm{a}$ \\
\hline & Species & $* *$ & $* *$ & $* *$ & & & & & & \\
\hline & Input & Ns & Ns & Ns & & & & & & \\
\hline & Species $\mathrm{x}$ Input & Ns & $* *$ & Ns & & & & & & \\
\hline \multirow[t]{5}{*}{ Marches } & $\mathrm{C}$ & 1.28 & 1.00 & 1.13 & 42.3 & 41.7 & 42.0 & 0.55 & 0.42 & 0.49 \\
\hline & $\mathrm{H}$ & 2.80 & 2.63 & 2.71 & 42.5 & 45.3 & 43.9 & 1.21 & 1.21 & 1.21 \\
\hline & Species & $* *$ & Ns & $* *$ & & & & & & \\
\hline & Input & Ns & Ns & Ns & & & & & & \\
\hline & Species $x$ Input & Ns & Ns & Ns & & & & & & \\
\hline \multirow[t]{5}{*}{ Apulia } & $\mathrm{C}$ & 1.60 & 1.36 & 1.48 & 38.3 & 35.0 & 36.6 & 0.61 & 0.47 & 0.54 \\
\hline & $\mathrm{R}$ & 2.27 & 2.32 & 2.29 & 44.6 & 48.0 & 46.3 & 1.01 & 1.11 & 1.06 \\
\hline & Species & $* *$ & $* *$ & $* *$ & & & & & & \\
\hline & Input & Ns & Ns & Ns & & & & & & \\
\hline & Species $\mathrm{x}$ Input & Ns & $* *$ & Ns & & & & & & \\
\hline
\end{tabular}

* C stands for Brassica carinata; $\mathrm{R}$ for rapeseed; $\mathrm{H}$ for high oleic sunflower. DM Dry Matter; HI high input cultivation techniques; LI low input cultivation techniques.

$* * \mathrm{P} \leq 0.01$ ns not significant.

higher amount of carbon in oil crops (Gan et al., 2009). This could permit a sequestration of more than $300 \mathrm{~kg}$ of $\mathrm{CO}_{2}$ for each ton of biomass incorporated in soil, calculated using the isohumic coefficient of $15 \%$.

Finally, the evaluation of the energy and environmental balances expressed as $\mathrm{CO}_{2}$ equivalents of the cultivation of carinata in four different localities is reported in Table 7. Seed oil content, needed for biodiesel yield evaluation, was $32.5 \%$ in Budrio, $35.0 \%$ in Gravina, $41.5 \%$ in S. Piero a Grado and $31.8 \%$ in Po di Tramontana. NCV resulted $37.66 \mathrm{MJ} \mathrm{kg}^{-1}$ for B.carinata oil and $18.19 \mathrm{MJ} \mathrm{kg}^{-1}$ for B.carinata DSM. The values in the last column of the Table 7 reports the $\mathrm{CO} 2 \mathrm{eq}$ emission considering the two co-products with an equal relevance, and obtained taking into account of a loss of $2 \%$ with respect to the grain quantity. The $2 \%$ of mass losses is a value measured after oil extraction in the plant used in the project.

The results clearly show how Po di Tramontana trial presents a higher value of needed Energy during process $(\mathrm{En} / \mathrm{S})$ when compared to the other sites where low input cultivation techniques had been applied. As a consequence, referring to a MJ of biodiesel, energy efficiency (expressed as obtained energy / needed energy) is in this case lower than one, while in the other three environments it is higher than 1.3.

$\mathrm{CO}_{2}$ eq standard emissions for carinata are not present in the EU Dir 2009/28/EC (Annex

Table 6. Chemical composition of defatted seed meals (DSM) from rapeseed, sunflower and carinata.

\begin{tabular}{lccccccc}
\hline & & $\begin{array}{c}\text { Moisture } \\
\%\end{array}$ & $\begin{array}{c}\text { Oil content } \\
\% \text { DM }\end{array}$ & $\begin{array}{c}\text { N content } \\
\% \text { DM }\end{array}$ & $\begin{array}{c}\text { Total P content } \\
\% \text { DM }\end{array}$ & $\begin{array}{c}\text { Organic C } \\
\% \text { DM }\end{array}$ & $\begin{array}{c}\text { Glucosinolates } \\
\left(\mathrm{mmoles} \mathrm{kg}^{-1} \mathrm{DM}\right)\end{array}$ \\
\hline Carinata & Mean & 4.9 & 11.0 & 5.5 & 0.9 & 34.6 & 95.9 \\
& SD & 0.9 & 1.5 & 0.3 & 0.1 & 0.8 & 5.5 \\
\hline HOSO & Mean & 5.7 & 12.0 & 5.0 & 0.8 & 35.1 & Absent \\
& SD & 1.2 & 1.3 & 0.2 & 0.1 & 1.0 & 25.1 \\
\hline Rapeseed & Mean & 7.2 & 13.4 & 4.9 & 0.8 & 34.4 & 2.0 \\
& SD & 1.5 & 1.4 & 0.3 & 0.1 & 1.2 & 2.0 \\
\hline
\end{tabular}

$\mathrm{DM}=$ Dry Matter; $\mathrm{C}=$ Carbon; $\mathrm{P}=$ Phosphorus. 
Table 7. Energy requirements and GHG emissions as $\mathrm{CO}_{2}$ equivalent.

\begin{tabular}{|c|c|c|c|c|c|c|c|c|c|c|c|}
\hline \multirow[t]{2}{*}{ Locality } & \multicolumn{2}{|c|}{ Yield (DM) } & \multicolumn{2}{|l|}{$\mathrm{En} / \mathrm{S}$} & \multirow{2}{*}{$\begin{array}{c}\mathrm{En} / \mathrm{P} \\
\text { Biodiesel } \\
M J \\
\mathrm{~kg}^{-1}\end{array}$} & \multicolumn{2}{|c|}{ Eo/En } & \multirow{2}{*}{ 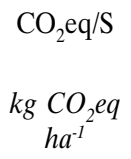 } & \multirow{2}{*}{$\begin{array}{c}\mathrm{CO}_{2} \mathrm{eq} / \mathrm{P} \\
\text { grain } \\
\mathrm{kg} \mathrm{CO}_{2} e q \\
\mathrm{~kg}^{-1}\end{array}$} & \multirow{2}{*}{$\begin{array}{c}\mathrm{CO}_{2} \mathrm{eq} / \mathrm{MJ} \\
\text { biodiesel }(*) \\
g \mathrm{CO}_{2} e q \\
\mathrm{MJ}^{-1}\end{array}$} & \multirow{2}{*}{$\begin{array}{c}\mathrm{CO}_{2} \mathrm{eq} / \mathrm{MJ} \\
\text { biodiesel(**) } \\
\mathrm{g} \mathrm{CO}_{2} \mathrm{eq} \\
\mathrm{MJ}^{-1}\end{array}$} \\
\hline & $\begin{array}{l}\text { Grain } \\
k g h a^{-1}\end{array}$ & $\begin{array}{c}\text { Biodiesel } \\
k g h a^{-1}\end{array}$ & $\begin{array}{l}M J \\
h a^{-1}\end{array}$ & $\begin{array}{c}\text { Grain } \\
M J \\
k g^{-1}\end{array}$ & & $\begin{array}{c}\text { Grain } \\
M J \\
M J^{-1}\end{array}$ & $\begin{array}{c}\text { Biodiesel } \\
M J \\
M J^{-1}\end{array}$ & & & & \\
\hline Budrio & 1700 & 357 & 9496 & 5.59 & 26.62 & 4.01 & 1.39 & 609 & 0.36 & 46 & 10.12 \\
\hline $\begin{array}{l}\text { Gravina } \\
\text { in Puglia }\end{array}$ & 1400 & 328 & 6939 & 4.96 & 21.16 & 4.61 & 1.75 & 424 & 0.30 & 35 & 8.56 \\
\hline $\begin{array}{l}\text { San Piero } \\
\text { a Grado }\end{array}$ & 1840 & 548 & 9417 & 5.12 & 17.19 & 4.71 & 2.15 & 738 & 0.40 & 36 & 11.33 \\
\hline $\begin{array}{l}\text { Po di } \\
\text { Tramontana }\end{array}$ & 1730 & 351 & 20311 & 11.74 & 57.83 & 1.89 & 0.64 & 1271 & 0.73 & 98 & 20.76 \\
\hline
\end{tabular}

$\mathrm{DM}=$ Dry Matter; En = needed Energy; Eo = obtained Energy; $\mathrm{S}=$ surface; $\mathrm{P}=$ product.

* $\mathrm{CO}_{2}$ eq emission considering biodiesel the unique useful product of the process.

** $\mathrm{CO}_{2}$ eq emission considering the oilcake as useful co-product of biodiesel and a total mass loss of $2 \%$.

$\mathrm{V}$ part D) and for comparison the value of rapeseed has been assumed. For this crop, the $\mathrm{CO}_{2}$ eq emissions for the production of one $\mathrm{MJ}$ of biodiesel related to the cultivation phase is 29 $\mathrm{gCO}_{2} \mathrm{eq} / \mathrm{MJ}$. Considering biodiesel as the unique useful product of the process, in no case $\mathrm{CO}_{2}$ eq emissions resulted lower than the reference value. On the contrary, considering as useful outputs also DSM as co-product of oil extraction, the $\mathrm{CO}_{2}$ eq cultivation-phase emissions for a $\mathrm{MJ}$ of biodiesel were widely lower than the limits reported by in the Dir. 2009/28/EC.

Note how the better performances in balances among low input treatments was obtained in Gravina trial due to lower inputs applied in Apulia, although San Piero yield and oil content resulted higher.

The "Bioenergie" project was presented and discussed in more than thirty demonstrative meetings carried out at National level. Its proposal could represent a potential sustainable opportunity for the entire agricultural system of the Mediterranean basin. The results highlight the possibility of improving the sustainability of bioenergy chains in many Italian region adopting low external input cropping systems, choosing the right crop and valorising oil crop product and co-product at local level.

\section{Acknowledgements}

The reported data are only a part of the results obtained in the framework of the oil crop chain of the project "Energie da biomasse agricole e forestali: miglioramento ed integrazione delle filiere e dei biocarburanti e della fibra per la produzione di energia elettrica e termi- ca" financed by the MiPAF and coordinated by CRA. We want to thank the regional extension service for agriculture that actively cooperated in the open field trials organisation and in demonstration activities. In particular: Veneto Agricoltura for Veneto, CRPV for Emilia Romagna, ARSIA Toscana for Tuscany, ASSAM for Marches, the Assessorato alle Risorse Agroalimentari for Apulia, Biopower Sardinia and Disageva for Sardinia, Assessorato Regionale agricoltura e Foreste for Sicily.

Finally, we thank the Italian Society of Agronomy (SIA) and the Green Chemistry Association (Chimica Verde bionet) for the patronage of demonstrative activities.

\section{References}

Andrews S.S., Mitchell J.P. Mancinelli R. Karlen D.L. Horwath W.R., Pettygrove G.S., Scow K.M, Munk D.S. 2002. On-farm assessment of soil quality in California's Central Valley. Agron. J., 94:12-23.

Audsley E. (Co-Ordinator). 1997. Harmonization of Environmental Life Cycle Assessment for Agriculture. Final Report Concerted Action AIR3-CT94-2028, European Commission DG VI Agriculture, 103 pp.

Bezzi G., Lazzeri L., Monti A., Venturi G. 2007. Brassica carinata un'interessante coltura oleaginosa per bioraffineria. Dal Seme, 2/07:56-63.

CEN/TS 14918, 2005. Solid biofuels: Method for determination of calorific value.

Consoli F., Allen D., Boustead I., Franklin W., Jensen A., De Oude N., Parrish R., Perriman R., Postlethwaite D., Quay B., Seguin J., Vigon B. 1993. Guidelines for Life Cycle Assessment: A Code of Practice, SETAC Press, Pensacola, Florida, 1-69.

Costantini E. 2004. Facciamo i conti con l'humus. Bioagricoltura, 4:32-35.

Cottenie A., Verloo M., Velghe G., Comerlynk R. 1982. In Chemical analysis of plant and soil. Laboratory of analytical and agro-chemistry. State University. Ghent, Belgium. 
Freibauer A, Rounsvell M.D.A., Smith P., Verhagen J. 2004. Carbon sequestration in the agricultural soils of Europe. Geoderma, 122:1-23.

Furlan L., Bonetto C., Patalano G., Lazzeri L. 2004. Potential of biocidal meals to control wireworm populations. Proceedings of the first International Symposium on "Biofumigation: a possible alternative to methyl bromide?" Firenze (IT), 31 marzo - 1 aprile. Agroindustria, 3:313-316.

Gan Y.T., Campbell C.A., Janzen H.H., Lemke R.L., Basnyat P., Mc Donald C.L. 2009.

Carbon input to soil from oilseed and pulse crops on the Canadian prairies. Agr. Ecosyst. Environ., 132:290-297.

Kamm B., Gruber P. R., Kamm M. 2006. Biorefineries Industrial Processes and Products. Status Quo and Future Directions. Vol. 1, 56-65. Edited by ed. WILEY-VCH Verlag GmbH \& Co. KGaA, Weinheim.

Janssens I.A., Freibauer A., Ciais P., Smith P., Nabuurs G.-J., Folberth G. 2003. Europe's terrestrial biosphere absorbs $7-12 \%$ of European anthropogenic $\mathrm{CO}_{2}$ emissions. Science, 300:1538-1542.

IPCC, 2001. Climate change 2001: The scientific basis. Available at http:/www.grida.no/publications/other/ ipcc_tar/.).

Lazzeri L., Leoni O., Mazzoncini M., D’Avino L., Patalano G. 2007a. Residual Defatted Seed Meal from Oleaginous Brassicaceae Crops as Soil Amendments to Improve Economical and Energetic Balance of Biodiesel Production - EPOBIO Workshop "Products from plants from crops and forests to zero-waste biorefineries", 1517 May 2007, Athens, Greece available at http:// www.epobio.net/workshop0705/0705posters.htm.

Lazzeri L., Leoni O., Palmieri S., Cinti S., Malaguti L., Curto G., Patalano G. 2007b. Brevetto N. BO $2007^{\circ}$ 000233. Ammendante agricolo a base di farine vegetali ed uso di tale ammendante. Ufficio italiano brevetti e marchi.

Lazzeri L., D’Avino L. 2008. Bioraffinerie da biomasse dedicate. In: Le bioraffinerie: percorso integrato per la valorizzazione di rifiuti organici e dei sottoprodotti/residui/effluenti agroalimentari. Atti dei seminari, Ecomondo 2008, Maggioli editore, San Marino, Vol. 1, 105-110.

Lazzeri L., Curto G., Dallavalle E., D’Avino L., Malaguti L., Santi R., Patalano G. 2009. Nematicidal efficacy of biofumigation by defatted Brassicaceae meal for control of Meloidogyne incognita (Kofoid et White) Chitw. on zucchini crop. J. Sustain. A., 33:349-358.

Lazzeri L., Mazzoncini M., De Mastro G. Brassica carinata Braun una nuova coltura oleaginosa ad integrale utilizzazione non alimentare. In press on Agriforenergy.

Mazzoncini M., Vannozzi G.P., Megale P., Secchiari P., Pistoia A., Lazzeri L. 1993. Ethiopian mustard (Brassica carinata A. Braun) crop in central Italy. Note 1: characterization and agronomic evaluation. Agr. Med., 123:330-338.

Sooby J. 2001. On-Farm Research Guide. Santa Cruz, CA: Organic Farming Research Foundation. http:// ofrf.org/grants/on-farm_research_guide.pdf.

Tanaka D.L., Krupinsky J.M., Liebig M.A., Merrill S.D., Ries R.E., Hendrickson J.R., Johnson H.A., Hanson J.D. 2002. Dynamic cropping systems: An adaptable approach to crop production in the Great Plains. Agron. J., 94:957-961.

Venturi P., Venturi G. 2003. Analysis of energy comparison for crops in European agricultural systems. Biomass and Bioenergy, 25:235-255.

Wuest S.B., McCool D.K., Miller B.C., Veseth R.J. 1999. Development of more effective conservation farming systems through participatory on-farm research. Am. J. Altern. Agric., 14:98-102.

Zanetti F., Vamerali T., Mosca G. 2009. Yield and oil variability in modern varieties of high-erucic oilseed rape (Brassica napus L. var. oleifera) and Ethiopian mustard (Brassica carinata) under reduced agricultural inputs. Ind. Crops \& Prod., 30:265-270. 